\title{
Er selvmordsforsøkere som også selvskader, en unik gruppe? ${ }^{11}$
}

\author{
Ved Maria Ramberg og Barbara Stanley
}

\begin{abstract}
Forskning har gitt klinikken økt kunnskap om selvmordsforsøkere og om fenomenet selvskading, men klinisk er en tredje gruppe velkjent og langt mindre studert - de pasientene som både gjør selvmordsfors $\emptyset \mathrm{k}$ og som selvskader. I studien som omtales her, undersøkes nettopp denne gruppen. Studien gir viktig klinisk kunnskap.
\end{abstract}

Selvskading er her definert som villet egenskade uten suicidal intensjon. De vanligste formene er kutting og brenning (Herpertz, 1995; Favazza, 1992). Personer med borderline personlighetsforstyrrelse som har selvskadet, har betydelig høyere risiko for å d $\varnothing$ av selvmord. Selvskading er mest utbredt hos pasienter diagnostisert med borderline personlighetsforstyrrelse (Langbehn og Pfohl, 1993), en gruppe som har en livstidsprevalens for selvmord på 5-10 \% (Fyer et al., 1988; Frances et al., 1986; Stone et al., 1987). Omtrent 55-85\% av selvskadere har gjort minst ett selvmordsfors $\varnothing \mathrm{k}$ (Dulit et al., 1994; Stanley et al., 1992; Roy, 1978; Rosenthal et al., 1972; Gardner og Gardner, 1975; Favazza og Conterio, 1989). Til tross for de høye morbiditets- og mortalitetsratene beskrives ofte selvmordsatferd hos denne gruppen som ikke reelt livstruende eller "ekte" (Bongar et al., 1990), men primært som oppmerksomhetss $\varnothing$ kende og manipulerende. Dette synet bør endres fordi opptil $10 \%$ av denne gruppen d $\varnothing \mathrm{r}$ ved selvmord. Det er mulig at selvmordsfare hos pasienter med både borderline personlighetsforstyrrelse og selvskading fremstår så annerledes fra andre pasienter at alvorlighetsgraden kan undervurderes av helsearbeidere.

Selvskading karakteriseres ved en stigende indre spenning før handlingen med sterke og vedvarende tanker om å skade seg selv (Gardner og Cowdry, 1985). På et tidspunkt blir spenningen overveldende, og personen klarer ikke, eller ønsker ikke lenger å stå imot, og gir etter for trangen til å skade seg selv. Selvskaderne oppgir et spekter av forskjellige motiver, for eksempel selvstraff eller spenningsreduksjon. Etter handlingen rapporterer de en følelse av å føle seg bedre, og også lettet (Herpertz, 1995; Favazza, 1992; Favazza og Conterio, 1989; Kemperman et al., 1997).
Suicidale følelser karakteriseres sjelden på denne måten. Følelser av håpløshet, fortvilelse og depresjon dominerer

(Fawcett et al., 1987). Kanskje finnes det en undertype av selvmordsatferd som har død som sitt mål, men som oppleves med et emosjonelt og kognitivt mønster som det man finner ved selvskading. Stanley et al. (1991) vurderer intensjonen med selvmordsatferd som noe distinkt annet enn selvskading, men det kan være egenskaper ved opplevelsen som er like. Hvis det er riktig, kan det være mer effektivt å behandle selvmordsatferd hos selvskadende pasienter på samme måte som selvskading. Dette vil innebære en annen tilnærming enn å forstå selvmordsatferden som en manifestasjon av depresjon, og hvor det å behandle den affektive lidelsen reduserer risikoen for suicidal atferd. I denne studien ser man på en gruppe selvmordsfors $\varnothing$ kere med en cluster B personlighetsforstyrrelse, og sammenligner innad i gruppen de som har en historie med selvskading med de som ikke har en slik historie. Hensikten med studien er

1) å sammenligne selvmordsfors $\varnothing$ kere med cluster B personlighetsforstyrrelse som også selvskadet med de som ikke selvskadet, for å unders $\varnothing$ ke om selv skadende selvmordsfors $\varnothing$ kere skiller seg klinisk fra selvmordsfors $\varnothing$ kere uten selvskading.

2) å unders $\varnothing \mathrm{ke} \mathrm{om} \mathrm{selvmordsfors} \varnothing$ kene til selvskaderne skilte seg fra fors $\varnothing$ kene til de som ikke selvskadet.

Dette er den første studien som sammenligner selvskadende selvmordsfors $\varnothing$ kere med en diagnostisk matchet gruppe av selvmordsfors $\varnothing$ kere uten selvskadingshistorie. Resultatene av denne studien kan hjelpe klinikeren i å vurdere suicidalitet $\mathrm{i}$ en gruppe pasienter som er vanskelige å vurdere og behandle.

\section{Metode}

\section{Utvalg}

53 psykiatriske pasienter med en DSMIII-R-diagnose med cluster B personlighetsforstyrrelse og minst et selvmordsfors $\varnothing \mathrm{k}$ deltok i studien. Eksklusjonskriteriene var pågående rusmisbruk eller rusavhengighet, opplevd hodetraume med påfølgende komat $\varnothing$ s tilstand, mental retardasjon eller annen betydelig kognitiv svekkelse som ville påvirke pasientens evne til å delta i studien. Alle deltakere ga skriftlig samtykke til å delta.

De 53 pasientene hadde en gjennomsnittsalder på 29,9 år (SD=10, intervall= 18-65), de fleste var kvinner $(\mathrm{N}=42$, $79 \%)$, kaukasiere ( $\mathrm{N}=47,89 \%)$, enslige $(\mathrm{N}=37,70 \%)$, uten barn $(\mathrm{N}=43,81 \%)$ og uten arbeid $(\mathrm{N}=35,66 \%) .50$ (94\%) av pasientene var diagnostisert med borderline personlighetsforstyrrelse, de siste 3 hadde andre typer av cluster B personlighetsforstyrrelser. 35 (66\%) hadde komorbid depresjon.

Alle pasientene hadde gjort minst ett selvmordfors $\varnothing \mathrm{k}$; livstidsprevalensen var 3,0 fors $\varnothing \mathrm{k}(\mathrm{SD}=2,4)$. Utvalget ble delt inn i to undergrupper: Pasientene som hadde selvskadet dvs. påført seg vevsskade med vilje uten intensjon om å d $\varnothing$, og pasientene som ikke hadde selvskadet. Pasientene med selvskading og minst ett selvmordfors $\varnothing \mathrm{k}$ utgjorde gruppen med selvskading, $\mathrm{N}=30$, og de med minst et selvmordfors $\varnothing \mathrm{k}$ men uten selvskading utgjorde gruppen uten selvskading, $\mathrm{N}=23$.

\section{Utredning}

For beskrivelse av de forskjellige instrumentene som ble brukt, henvises leser til originalartikkelen. Her vil instrumentene kun nevnes summarisk.

Suicidalitet ble målt ved flere klinikeradministrerte skalaer og instrumenter slik som Suicide Intent Scale (SIS)(Beck et al., 1974) og Scale for Suicide Ideation (SSI) (Beck et al., 1979) og ved en grundig kartlegging av tidligere suicidal atferd.

\footnotetext{
1) Dette er en oversatt og forkortet utgave av artikkelen Stanley B., Gameroff M.J., Michalsen V. \& Mann J.J. Are suicide attempters who selfmutilate a unique population? American Journal of Psychiatry 2001, 158, 427-432. Maria Ramberg har oversatt artikkelen og i samarbeid med Barbara Stanley skrevet avsnittet "Forskning i dag" for Suicidologi
} 
Pasientene ble diagnostisert av erfarne klinikere etter DSM-III-R-kriterier på grunnlag av flere intervjuinstrumenter (Baron, 1980; Spitzer og Endicott, 1978). Aggresjon ble målt ved et semistrukturert instrument modifisert fra Brown-Goodwins skala for aggresjon (livstid) (Brown et al., 1979) og ved Buss-Durkees Inventorium for fiendtlighet (Buss og Durkee, 1957). Depressive symptomer ble målt med Hamiltons skala for depresjon (HDRS) (Guy, 1976) og håpløshet ved Becks håpløshetsskala (BHS)(Beck et al., 1974). Nåværende psykotiske symptomer ble målt ved Brief psychiatric rating scale (BPRS) (Guy, 1976). Informasjon om fysiske og seksuelle overgrep i barndommen ble innsamlet gjennom et semistrukturert klinisk intervju.

\section{Statistiske analyser}

For å sammenligne gruppene på kontinuerlige variabler benyttet man tosidige T-tester, og kji-kvadrat-analyser for kategoriske variabler.

\section{Resultater}

\section{Sosiodemografiske variabler}

Det var ikke signifikante forskjeller på alder, kjønn, etnisitet, sivilstatus, religion, utdannelsesnivå eller jobbsituasjon (tab. 1) mellom gruppene. Antall pasienter med pågående alvorlig depresjon var likt i gruppene (data ikke vist). 17 \% av gruppen med selvskading og $26 \%$ av gruppen uten selvskading hadde en familiehistorie med enten selvmordsfors $\varnothing \mathrm{k}$ eller selvmord i første slektsledd (tabell 1).

Antall innleggelser i psykiatrien i hver gruppe var tilnærmet likt (gj.snitt $=3,1$, $\mathrm{SD}=3,8$ for med selvskading, gj.snitt $=3,0$ og $\mathrm{SD}=3,0$ foruten selvskading) $(\mathrm{t}<1$, $\mathrm{df}=49$ ikke signifikant). Det var ingen signifikante forskjeller i antall pasienter som tidligere hadde mottatt psykoterapi.

\section{Aggresjon og overgrepshistorie}

Gruppen med selvskading viste mer aggressiv atferd, hadde signifikant høyere skåre på Brown-Goodwins aggresjonsskala (livstid) (tabell 2). Det var ikke signifikant forskjell på Buss-Durkees Inventorium for fiendtlighet. Gruppen med selvskading rapporterte betydelig høyere frekvens av fysiske avstraffelser i barndommen, men ikke høyere frekvens av seksuelle overgrep. Det var ikke signifikant forskjell på graden av vold brukt i fysiske overgrep i de to gruppene.
Tabell 1: Demografiske kjennetegn på selvmordsforsøkere med cluster B personlighetsforstyrrelse med og uten selvskading.

\begin{tabular}{|c|c|c|c|c|c|c|c|}
\hline \multirow[t]{2}{*}{ Kjennetegn } & \multicolumn{2}{|c|}{$\begin{array}{l}\text { Selvskading } \\
\qquad(\mathrm{N}=30)\end{array}$} & \multicolumn{2}{|c|}{$\begin{array}{c}\text { Uten } \\
\text { selvskading } \\
(N=23)\end{array}$} & \multicolumn{3}{|c|}{ Analyse } \\
\hline & Gj.sn. & SD & Gj.sn. & SD & $\mathrm{t}$ & df & $\mathrm{p}$ \\
\hline \multirow[t]{2}{*}{ Alder } & 29,3 & 8,6 & 30,8 & 11,6 & $<1$ & 51 & n.s. \\
\hline & $\mathrm{N}$ & $\%$ & $\mathrm{~N}$ & $\%$ & $x^{2}$ & df & $\mathrm{p}$ \\
\hline Kvinne & 26 & 86,7 & 16 & 69,6 & 2,32 & 1 & n.s. \\
\hline Etnisk opprinnelse & & & & & $<1$ & 1 & n.s. \\
\hline Kaukasisk & 26 & 86,7 & 21 & 91,3 & & & \\
\hline Latin-amerikansk & 2 & 6,7 & & & & & \\
\hline Afroamerikansk & 1 & 3,3 & & & & & \\
\hline Asiatisk & 1 & 3,3 & 2 & 8,7 & & & \\
\hline Sivil status & & & & & 1,76 & 3 & n.s. \\
\hline Enslig & 22 & 73,3 & 15 & 65,2 & & & \\
\hline Gift & 2 & 6,7 & 2 & 8,7 & & & \\
\hline Separert & 2 & 6,7 & 4 & 17,4 & & & \\
\hline Skilt & 4 & 13,3 & 2 & 8,7 & & & \\
\hline Har barn & 6 & 20,0 & 4 & 17,4 & $<1$ & 1 & n.s. \\
\hline Utdannelse & & & & & 4,31 & 4 & n.s. \\
\hline Ikke gj.ført high school & 1 & 3,3 & 3 & 13,0 & & & \\
\hline High scool & 4 & 13,3 & 5 & 21,7 & & & \\
\hline Ikke gj.ført college & 14 & 46,7 & 8 & 34,8 & & & \\
\hline College & 8 & 26,7 & 3 & 13.0 & & & \\
\hline Graduate school & 3 & 10,0 & 4 & 17,4 & & & \\
\hline Trosretning & & & & & 6,40 & 4 & n.s. \\
\hline Katolisisme & 8 & 26,7 & 9 & 39,1 & & & \\
\hline Protestantisme & 2 & 6,7 & 5 & 21,7 & & & \\
\hline Jødedom & 7 & 23,3 & 1 & 4,3 & & & \\
\hline Ingen & 6 & 20,0 & 3 & 13,0 & & & \\
\hline Andre & 6 & 20,0 & 4 & 17,4 & & & \\
\hline I arbeid & 11 & 36,7 & 7 & 30,4 & $<1$ & 1 & n.s. \\
\hline Selvmordsatferd i familien & 5 & 16,7 & 6 & 26,1 & 1,10 & 1 & n.s. \\
\hline
\end{tabular}

Tabell 2: Sumskåre fra instrumenter som måler psykiske symptomer, hentet fra gruppen selvmordsforsøkere med cluster B personlighetsforstyrrelse med og uten selvskading

\begin{tabular}{|c|c|c|c|c|c|c|c|}
\hline \multicolumn{8}{|c|}{ Skåre } \\
\hline & \multicolumn{2}{|c|}{$\begin{array}{c}\text { Selvskading } \\
(\mathrm{N}=30)\end{array}$} & \multicolumn{2}{|c|}{$\begin{array}{c}\text { Uten } \\
\text { selvskading } \\
(\mathrm{N}=23)\end{array}$} & \multicolumn{3}{|c|}{ Analyse } \\
\hline Skalaer & Gj.sn. & SD & Gj.sn. & SD & $\mathrm{t}$ & df & $\mathrm{p}$ \\
\hline $\begin{array}{l}\text { Brown-Goodwins skala for } \\
\text { aggresjon (livstid) }\end{array}$ & 22,5 & 5,2 & 18,8 & 5,2 & 2,47 & 547 & $<0,02$ \\
\hline Hamiltons skala for depresjon (HDRS) & 24,4 & 7,2 & 19,1 & 9,4 & 2,25 & 48 & $<0,03$ \\
\hline Becks håpløshetsskala (BHS) & 12,0 & 4,0 & 9,0 & 5,5 & 2,19 & 46 & $<0,04$ \\
\hline Brief psychiatric rating scale (BPRS) & 40,1 & 8,4 & 35,2 & 8,8 & 1,90 & 42 & $<0,07$ \\
\hline Buss-Durkees Invent. for fiendtlighet & 45,0 & 10,7 & 42,4 & 10,5 & $<1$ & 46 & n.s. \\
\hline Brief psychiatric rating scale (BPRS) & 4,4 & 0,8 & 4,3 & 1,0 & $<1$ & 34 & n.s. \\
\hline
\end{tabular}




\section{Psykiske symptomer}

En oversikt over begge gruppene er presentert i tabell 2 .

Gruppen med selvskading var mer deprimert som målt ved Hamiltons skala for depresjon (HDRS). Likevel var frekvensen av pågående alvorlig depressiv episode lik i begge gruppene, $70 \%$ i gruppen med selvskading og $61 \%$ i gruppen uten, men gruppen med selvskading hadde altså en alvorligere grad av depresjon. De skåret også signifikant høyere på BHS (tabell 2).

Gruppen med selvskading skåret ikke signifikant høyere på BPRS, men i tråd med funnene fra Hamiltons skala for depresjon skåret selvskaderne høyere på BPRS-subskalaene for angst og depresjon. Selv om nesten alle pasientene i begge gruppene hadde borderline personlighetsforstyrrelse, demonstrerte selvskadergruppen en mer alvorlig borderlinepatologi (tabell 3).

\section{Selvmordsatferd og selvmordstanker}

Det var forskjell på gruppene når det gjelder suicidalitet (tabell 4). Selv om alle pasientene i den ene gruppen selvskadet, brukte majoriteten av pasientene i begge gruppene $(77 \%$ og $74 \%$ ) piller da de gjorde selvmordsfors $\varnothing \mathrm{k}$. Den nest mest brukte metoden var kutting: Gruppen med selvskading brukte denne metoden dobbelt så hyppig (17 \% mot $9 \%$ ). Det var ikke forskjell på gruppene $\mathrm{i}$ antall selvmordsfors $\varnothing \mathrm{k}$, tid siden forrige selvmordsfors $\varnothing \mathrm{k}$ eller skåre på SIS og SSI (tabell 5).
Begge grupper hadde et gjennomsnitt på tre selvmordsfors $\varnothing \mathrm{k}$, og risikoen for å d $\varnothing$ av handlingene ble vurdert som relativt alvorlig (bevisstløse, moderate overdoser) (tabell 5).

Selv om gruppenes dødsrisiko ved de suicidale handlingene ble vurdert som lik, undervurderte gruppen med selvskading alvorligheten i sine fors $\varnothing \mathrm{k}$. Sammenlignet med gruppen uten selvskading, vurderte gruppen med selvskading at deres like dødelige selvmordsfors $\varnothing \mathrm{k}$ (som vurdert av forskerne) mindre sannsynlig ville resultere i $\mathrm{d} \varnothing \mathrm{d}$ (tabell 5).

Tabell 3: Trekk fra borderline personlighetsforstyrrelse hos selvmordsforsøkere med cluster B personlighetsforstyrrelse med og uten selvskading.

\begin{tabular}{|c|c|c|c|c|c|}
\hline \multicolumn{6}{|c|}{ Skåre } \\
\hline \multirow{2}{*}{$\begin{array}{l}\text { Trekk fra instrumentet } \\
\text { "skjema for intervju av borderlinere" }\end{array}$} & \multirow{2}{*}{$\begin{array}{l}\text { Selvskading } \\
(\mathrm{N}=30)\end{array}$} & \multirow{2}{*}{\begin{tabular}{|c|}
$\begin{array}{c}\text { Uten } \\
\text { selvskading } \\
(\mathrm{N}=23)\end{array}$ \\
Gj.sn. SD \\
\end{tabular}} & \multicolumn{3}{|c|}{ Analyse } \\
\hline & & & $\mathrm{t}$ & df & $\mathrm{p}$ \\
\hline Frekvens av impulsiv seksuell aktivitet & $1,9 \quad 1,0$ & $1,3 \quad 0,6$ & 2,46 & 49 & $<0,02$ \\
\hline Psykisk angst & $2,6 \quad 1,1$ & $2,0 \quad 0,8$ & 2,74 & 46 & $<0,01$ \\
\hline Somatiske symptomer på angst & $2,3 \quad 0,8$ & $1,8 \quad 0,6$ & 2,62 & 46 & $<0,05$ \\
\hline Affektiv instabilitet & $3,1 \quad 1,0$ & $2,4 \quad 1,1$ & 2,18 & 47 & $<0,05$ \\
\hline Tomhetsfølelse og kjedsomhet & $3,2 \quad 1,0$ & $2,4 \quad 1,0$ & 2,78 & 48 & 0,01 \\
\hline Følsom for personlig avvisning & $3,6 \quad 0,6$ & $2,7 \quad 0,9$ & 4,30 & 46 & $<0,001$ \\
\hline
\end{tabular}

Tabell 4: Metode brukt i siste selvmordsfors $\emptyset \mathrm{k}$ i gruppen selvmordsfors $\emptyset$ kere med cluster B personlighetsforstyrrelse med og uten selvskading

\begin{tabular}{|l|rc|cc|}
\hline \multicolumn{4}{|c|}{ Skåre } \\
\hline & \multicolumn{1}{|c|}{ Selvskading $(\mathrm{N}=30)$} & \multicolumn{2}{c|}{ Uten selvskading (N=23) } \\
\hline Metode & $\mathrm{N}$ & $\%$ & $\mathrm{~N}$ & $\%$ \\
\hline Overdose & 23 & 76,7 & 17 & 73,9 \\
\hline Kutt i håndledd/hals & 5 & 16,7 & 2 & 8,7 \\
\hline Henging & 1 & 3,3 & 1 & 4,3 \\
\hline Våpen & 1 & 3,3 & 0 & 0,0 \\
\hline Hopping & 0 & 0,0 & 2 & 8,7 \\
\hline Drukning & 0 & 0,0 & 1 & 4,3 \\
\hline
\end{tabular}

Tabell 5: Selvmordsatferd hos selvmordsforsøkere med cluster B personlighetsforstyrrelser med og uten selvskading

\begin{tabular}{|c|c|c|c|c|c|c|c|}
\hline \multirow[b]{2}{*}{ Atferd } & \multicolumn{2}{|c|}{$\begin{array}{c}\text { Selvskading } \\
(N=30)\end{array}$} & \multicolumn{2}{|c|}{$\begin{array}{c}\text { Uten } \\
\text { selvskading } \\
(\mathrm{N}=23)\end{array}$} & \multicolumn{3}{|c|}{ Analyse } \\
\hline & Gj.sn. & SD & Gj.sn & SD & $\mathrm{t}$ & df & $p$ \\
\hline Totalt antall selvmordsforsøk & 3,1 & 2,4 & 2,9 & 2,4 & $<1$ & 51 & n.s. \\
\hline Dødelighet av selvmordsforsøkene ${ }^{a}$ & 4,4 & 0,8 & 4,4 & 1,2 & $<1$ & 36 & n.s. \\
\hline Scale for Suicide Ideation (SSI) skåre & 14,1 & 11,2 & 13,2 & 10,0 & $<1$ & 49 & n.s. \\
\hline Suicide Intent Scale (SIS) skåre & 15,3 & 3,8 & 16,2 & 6,7 & $<1$ & 44 & n.s. \\
\hline Varighet av selvmordstanker ${ }^{b}$ & 1,3 & 0,7 & 0,4 & 0,7 & 4,34 & 41 & $<0,0005$ \\
\hline Frekvens av selvmordstankerc & 1,4 & 0,8 & 0,6 & 0,7 & 3,51 & 41 & $<0,001$ \\
\hline Forståelse av faren for død/dødelighet ${ }^{d}$ & 1,0 & 0,7 & 1,5 & 0,7 & 2,36 & 45 & $<0,03$ \\
\hline Forståelse av betydning av medisinsk hjelpe & 0,8 & 0,5 & 1,2 & 0,8 & 2,37 & 45 & $<0,04$ \\
\hline Visualisering av døden ${ }^{f}$ & 1,0 & 0,9 & 1,5 & 0,7 & 1,94 & 39 & $<0,07$ \\
\hline
\end{tabular}

a) $1=$ ingen fare (ingen effekt), $2=$ minimal fare, $3=$ mild fare, $4=$ moderat fare (dvs. kort bevissthetstap), $5=$ alvorlig fare, $6=$ ekstrem fare (dvs. lengre komatøs tilstand)

b) $0=$ korte flyktige perioder, $1=$ lengre perioder, 2=kronisk eller nesten kronisk

c) $0=$ sjelden, $1=$ intermitterende, $2=$ hyppig eller kontinuerlig

d) o=trodde ikke det var dødelig, $1=$ ikke sikker på dødelighet, $2=$ trodde det var dødelig

e) $0=$ trodde død var usannsynlig hvis man fikk medisinsk hjelp, $1=$ usikker på om død ville avverges med medisinsk hjelp, $3=$ sikker på å dø selv om man fikk medisinsk hjelp.

f) $0=$ et liv etter døden, gjenforening med døde slektninger,

$1=$ evig søvn, mørke, slutten på alt $2=$ ingen tanker om døden. 


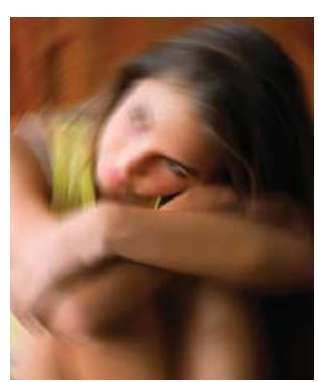

De selvskadende pasientene trodde i større grad de ville bli reddet at døden var mindre sannsynlig hvis de fikk medisinsk hjelp, og at døden er som en søvnlignende tilstand eller en gjenforening med deres avdøde slektninger (tabell 5).

Selv om SSI- og SIS-skårene lå på samme nivå i begge grupper, opplevde gruppen med selvskading lengre og hyppigere episoder med suicidaltanker enn gruppen uten selvskading, og de var sikrere på sitt mot og sin evne til å gjøre et selvmordsfors $\varnothing \mathrm{k}$.

\section{Diskusjon}

Studien viste ingen forskjell i antall selvmordsfors $\varnothing \mathrm{k}$, dødsrisikoen i selvmordsfors $\varnothing$ kene eller alvorlighetsgraden av selvmordstankene mellom selvmordsfors $\varnothing \mathrm{k}$ ere med eller uten selvskading. Hvis selvmordsfors $\varnothing$ kere som selvskader, oftere hadde gjort "ufarlige" selvmordsfors $\varnothing \mathrm{k}$ som var ment å påvirke andre og var oppmerksomhetss $\varnothing$ kende i sin form, ville vi forvente å finne en lavere d $\varnothing$ delighet $\mathrm{i}$ denne gruppens selvmordsfors $\varnothing \mathrm{k}$. Slik var det ikke. Resultatene tyder også på at denne gruppen er spesielt plaget og kan ha en st $\varnothing$ rre selvmordsrisiko av flere grunner:

1) De rapporterer mer depresjon og håpløshet.

2) De er mer aggressive og har flere trekk fra diagnosen borderline personlighetsforstyrrelse relatert til affektiv instabilitet.

3) De undervurderer dødeligheten i sin selvmordsatferd, tror de vil bli reddet etter et selvmordsfors $\varnothing \mathrm{k}$ og ser på døden som mindre endelig.

4) De plages av selvmordstanker oftere og i lengre tidsperioder.

Selvskadende selvmordsfors $\varnothing$ kere i materialet hadde st $\varnothing$ rre tendens til å ha vært utsatt for overgrep i barndommen, de viste mer aggressiv atferd, hadde mer uttalte borderlinetrekk relatert til affektinstabilitet og vanskeligheter med mellommenneskelige relasjoner. Disse faktorene $\varnothing$ ker risikoen for selvmord og selvmordsfors $\varnothing \mathrm{k}$ (Fyer et al., 1988; Gardner og Cowdry, 1985; Mann et al., 1999).

I stress-sårbarhetsmodellen for forklaring av selvmordsatferd (Mann et al., 1999) var aggresjon/impulsivitet den faktoren som tydeligst skilte selvmordsfors $\varnothing$ kere fra ikke-fors $\varnothing$ kere. I denne studien identi- fiseres en undergruppe av selvmordsfors $\varnothing$ kere som hadde mer aggresjon enn andre selvmordsfors $\varnothing$ kere. Selvskadende selvmordsfors $\varnothing$ kere viste også st $\varnothing$ rre affektinstabilitet koblet med en følelse av tomhet, følsomhet for personlig avvisning og impulsiv seksuell aktivitet. Disse funnene antyder at selvskaderne kan ha en tendens til å stole på eksterne kilder for å regulere indre tilstander, ikke bare ved å selvskade, men også ved å bruke sine relasjoner (Frances et al., 1986; Gardner og Gardner, 1975; Fawcett et al., 1987; Soloff et al., 1994). Hvis slutten på et forhold også betyr tap av effektiv affektregulering, er det mer forståelig hvorfor et slikt tap kan lede til selvmordsatferd.

Det er interessant at risikoen for å d $\varnothing$ av selvmordsfors $\varnothing$ kene var like høy i begge gruppene. Begge gruppene hadde middels alvorlige fors $\varnothing \mathrm{k}$. Dette stiller spørsmålstegn ved den kliniske oppfatning om at selvmordsfors $\varnothing$ kene til selvskadere er fors $\varnothing \mathrm{k}$ på å få oppmerksomhet, og ikke trenger å tas like alvorlig som selvmordsfors $\varnothing$ kene til andre pasienter. Selvskadere har en tendens til å undervurdere dødsrisikoen i selvmordsfors $\varnothing$ kene sine, og oppfatter i mindre grad d $\varnothing$ den som endelig. De kan derfor underkommunisere alvorligheten i sin suicidalitet til klinikerne som får et dårligere grunnlag for sin vurdering av pasienten. Hvis selvskadere undervurderer d $\varnothing$ dsrisikoen i egne selvmordsfors $\varnothing \mathrm{k}, \varnothing \mathrm{ker}$ faren for at de kan $\mathrm{d} \phi$ på grunn av feilvurdering.

Studien viste at gruppen med selvskading opplevde oftere og mer vedvarende selvmordstanker enn gruppen uten selvskading. Selv om intensiteten av tankene var lik i gruppene, virket det som selvskaderne var mer plaget av selvmordstankene. Det kan være at suicidalitet i denne gruppen ligner mer på selvskadingstrang. Pasienter som selvskader, bruker mye av sin tid til å kjempe mot lysten/ trangen til å skade seg selv (Favazza og Conterio, 1989). Kanskje selvmordsforsøkene i denne gruppen har et lignende mønster som selvskading, et mønster hvor det er en $\varnothing$ kende lyst til å skade seg selv som avløses av en midlertidig lettelse etter selvskadingsatferd. Det kan forklare hvorfor disse pasientene ikke lenger er ute av seg, men fremstår rolige når de innlegges etter et selvmordsfors $\varnothing \mathrm{k}$. Det er et viktig poeng at forskjellene på gruppene i studien, ikke kan forklares av tilstedeværelsen eller fraværet av diagnosen personlighetsforstyrrelse. Alle pasientene i denne studien hadde en cluster B personlighetsforstyrrelse, og alle unntatt tre hadde borderline personlighetsforstyrrelse. Dette kan tyde på at det er noe spesifikt med selvskaderne som forandrer deres opplevelse av selvmordstanker.

Funnene i studiet indikerer at klinikere ikke bør undervurdere selvmordsfors $\varnothing \mathrm{k}$ ene til pasienter med kjent selvskading, selv om fors $\varnothing$ kene kan ligne ekstrem selvskade. Tendensen til at klinikere reagerer negativt på selvskadere, kan bidra til feilbedømmingen av risiko i denne populasjonen. Klinikere bør være klar over at pasientene selv kan feiltolke dødsrisikoen i sine fors $\varnothing \mathrm{k}$ og ikke forstå den reelle farlighetsgraden i handlingen.

\section{Forskning i dag}

I forskningsmiljøet som utførte studien, går man nå videre med nye studier av samme pasientgrupper; selvmordsfors $\varnothing \mathrm{k}$ ere med og uten selvskading. Denne gangen utf $\varnothing$ res unders $\varnothing$ kelsen i et utvalg pasienter med og uten cluster B personlighetsforstyrrelse og der cluster B personlighetsforstyrrelse brukes som en covariat. Fokuset er hvilke følelser de to gruppene opplever i minuttene etter et selvmordsfors $\varnothing \mathrm{k}$. Hypotesen er at gruppene vil rapportere forskjellige følelser: Gruppen med selvskading vil føle seg bedre slik det ofte rapporteres etter selvskadingsepisoder, mens gruppen uten selvskading ikke forventes å ha en slik effekt av selvmordsatferden.

I løpet av de siste 15 år har det blitt publisert flere studier der man finner selvskading hos personer uten borderline personlighetsforstyrrelse (Klonsky et al., 2003; Ross og Heath, 2002) og hos andre diagnosegrupper (Zlotnick et al., 1999; Nock et al., 2006; Jacobson \& Gould, 2007). Selvskading forståes derfor ikke lenger kun som et symptom assosiert med borderline personlighetsforstyrrelse, og det er mulig selvskading utgjør en egen atferdsforstyrrelse eller et eget klinisk syndrom (Favazza og Rosenthal, 1993; Muehlenkamp, 2005). Man har behov for studier som nettopp ser på hvilke mekanismer som ligger bak selvskadingen, og om disse mekanismene er avhengige av diagnose eller ikke. 
I diagnosesystemet DSM-IV er selvskading kun beskrevet som et kriterium for borderline personlighetsforstyrrelse, noe som gjør det problematisk å plassere selvskading hos pasienter som ikke fyller kriteriene for borderline diagnosen. Det foreligger forslag om å inkludere selvskading (non-suicidal self-injury) som egen diagnose i DSM-V (Muehlenkamp, 2005), noe som ville løst det kliniske problemet og trolig bidratt til en klarere distinksjon mellom selvskading og selvmordsatferd. Men det er fortsatt et spørsmål om det finnes tilstrekkelig forskning som st $\varnothing t t e r$ opp under forståelsen av selvskading som egen diagnose. Et annet forslag er å innføre en sjette akse i DSM V hvor suicidalitet dokumenteres som en separat diagnostisk kategori. En akse for selvmordsatferd ville i st $\varnothing$ rre grad få klinikere til å vurdere selvmordsrisikoen hos alle pasienter som kommer til psykiatrisk behandling, uavhengig av diagnose (Oquendo et al., 2008).

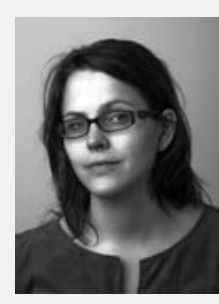

Maria Ramberg er lege og jobber som doktorgradstipendiat ved Nasjonalt senter for selvmordsforskning og -forebygging, Institutt for psykiatri, UiO. Hun jobber med behandlingsstudien om ungdom som skader seg selv. Hun er også DBT-terapeut.

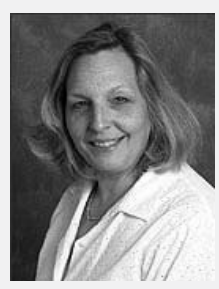

Professor Barbara Stanley, $\mathrm{PhD}$., er klinisk psykolog og forsker ved Department of Neuroscience, New York State Psychiatric Institute og Columbia University. Hun er leder for Center on Intervention for Prevention of Suicide ved Columbia og hun er redaktør for Archives of Suicidology. Hun har spesiell interesse for selvmordsatferd og borderline personlighetsforstyrrelse. Stanley er gjesteprofessor ved SSFF.

\section{Referanser}

Baron M., (1980): The Schedule for Interviewing Borderlines. New York: New York State Psychiatric Institute

Beck A.T., Kovacs M. \& Weissman A. (1979). Assessment of suicidal intention: the Scale for Suicide Ideation. J Consult Clin Psychol, 47, 343-352

Beck A.T., Schuyler D. \& Herman I. (1974). Development of suicidal intent scales. I Beck A.T., Resnick H.L.P., Lettieri D.J. Bowie (eds.). The Prediction of Suicide. Md, Charles Press, s. $45-58$
Beck A.T., Weissman A., Lester D. \& Trexler L. (1974). The measurement of pessimism: the Hopelessness Scale. J Consult Clin Psychol, 42, 861-865

Bongar B., Peterson L.G., Golann S. \& Hardiman J.J. (1990). Self-mutilation and the chronically suicidal patient: an examination of the frequent visitor to the psychiatric emergency room. Ann Clin Psychiatry, 2, 217-222

Brown G.L., Goodwin R.K., Ballenger J.C., Goyer P.F. \& Major L.F. (1979). Aggression in humans correlates with cerebrospinal fluid amine metabolites. Psychiatry Res, 1, 131-139

Buss A.H. \& Durkee A. (1957). An inventory for assessing different kinds of hostility. J Consult Psychol, 21, 343-349

Dulit R.A., Fyer M.R., Leon A.C., Brodsky B.S. \& Frances A.J. (1994). Clinical correlates of selfmutilation in borderline personality disorder. Am J Psychiatry, 151, 1305-1311

Favazza, A.R. (1992). Repetitive self-mutilation. Psychiatr Annals, 22(2), 60-63

Favazza A.R. \& Conterio K. (1989). Female habitual self-mutilators. Acta Psychiatr Scand, 79, 283-289

Favazza A.R. \& Rosenthal R.J. (1993): Diagnostic issues in self-mutilation. Hospital and Community Psychiatry, 44, 134-140

Fawcett J., Scheftner W., Clark D., Hedeker D., Gibbons R. \& Coryell W. (1987). Clinical predictors of suicide in patients with major affective disorders: a controlled prospective study. Am J Psychiatry, 144, 35-40

Frances A., Fyer M. \& Clarkin J. (1986).

Personality and suicide. I Mann J.J.\& Stanley B. (eds.). Psychobiology of Suicidal Behavior. New York: New York Academy of Sciences, s. 281-293

Fyer M.R., Frances A.J., Sullivan T., Hurt S.W. \& Clarkin J. (1988). Suicide attempts in patients with borderline personality disorder. Am J Psychiatry, 145, 737-739

Gardner D.L. \& Cowdry R.W. (1985). Suicidal and parasuicidal behavior in borderline personality disorder. Psychiatr Clin North Am, 8, 389-403

Gardner A.R. \& Gardner A.J. (1975). Selfmutilation, obsessionality and narcissism. $\mathrm{Br} \mathrm{J}$ Psychiatry, 127,127-132

Guy W. (ed.) (1976). ECDEU Assessment Manual for Psychopharmacology. Publication ADM 76-338. Washington, DC, US Department of Health, Education, and Welfare, s. 158-169

Guy W. (ed.) (1976): ECDEU Assessment Manual for Psychopharmacology. Publication ADM 76-338. Washington, DC, US Department of Health, Education, and Welfare, s. 180-192

Herpertz S. (1995). Self-injurious behavior: psychopathological and nosological characteristics in subtypes of self-injurers. Acta Psychiatr Scand, 91, 57-68

Jacobson C.M. \& Gould M. (2007): The epidemiology and phenomenology of non-suicidal self injurious behaviour among adolescents: a critical review of the literature. Arch Suicide Res,11(2), 129-147

Kemperman I., Russ M.J. \& Shearin E. (1997). Self-injurious behavior and mood regulation in borderline patients. J Personal Disord, 11, 146-157 Klonsky D.E., Oltermanns T.F. \& Turkheimer E. (2003). Deliberate self-harm in a nonclinical population: prevalences and psychological correlates. Am J Psychiatry, 160, 1501-1508

Langbehn D.R. \& Pfohl B. (1993). Clinical correlates of self-mutilation among psychiatric inpatients. Ann Clin Psychiatry, 5, 45-51

Mann J.J., Waternaux C., Haas G.L. \& Malone K.M. (1999). Toward a clinical model of suicidal behavior in psychiatric patients. Am J Psychiatry, 156, 181-189

Muehlenkamp J.J. (2005). Self-injurious

behaviour as a separate clinical syndrome. Am J Orthopsychiatry, 75 (2), 324-333

Nock M.K., Joiner T.E., Gordon K.H., LloydRichardson \& Prinstein M.J. (2006). Non-suicidal self-injury among adolescents: diagnostic correlates and relation to suicide attempts. Psych research, 144, 65-72

Oquendo M.A., Baca-Garcia E., Mann J.J. \& Giner J. (2008). Issues for DSM V: Suicidal behaviour as a separate diagnosis on a separate axis. Am J Psychiatry, ed. 165, 11

Rosenthal R.J., Rinzler C., Walsh R. \& Klausner E. ( 1972). Wrist-cutting syndrome: the meaning of a gesture. Am J Psychiatry, 128, 1363-1368

Roy A. (1978). Self-mutilation. Br J Med Psychol, 51, 201-203

Ross S. \& Heath N. (2002). A study of the frequency of self-mutilation in a community sample of adolescents. J Youth and Adolescense, 31, 67-77

Soloff P.H., Lis J.A., Kelly T., Cornelius J. \& Ulrich R. (1994). Self-mutilation and suicidal behavior in borderline personality disorder. J Personal Disord, 8, 257-267

Spitzer R.L. \& Endicott J. (1978). Schedule for Affective Disorders and Schizophrenia (SADS), 3rd ed. New York, New York State Psychiatric Institute, Biometrics Research.

Stanley B., Gameroff M.J., Michalsen V. \& Mann J.J. (2001). Are suicide attempters who selfmutilate a unique population? Am J Psych, 158, 427-432

Stanley B., Winchel R., Molcho A., Simeon D. \& Stanley M. (1992). Suicide and the self-harm continuum: phenomenological and biochemical evidence. Int Rev Psychiatry, 4, 149-155

Stone M., Hurt S. \& Stone D. (1987). The PI 500: long-term follow-up of borderline inpatients meeting DSM-III criteria, I: global outcome. J Personal Disord, 1, 291-298

Zlotnick C., Mattia J.I. \& Zimmerman M. (1999). Clinical correlates of self-mutilation in a sample of general psychiatric patients. J Nerv and Ment Dis, 187(5), 296-301. 